\title{
"La isla ingrávida”, poema atribuido al personaje Lila Borrero Pierra en la novela de José Prats Sariol Las penas de la joven Lila. Traducción de Anja Bernardy
}

José Prats Sariol

\section{Recommended Citation}

Prats Sariol, José. 2017. "La isla ingrávida”, poema atribuido al personaje Lila Borrero Pierra en la novela de José Prats Sariol Las penas de la joven Lila. Traducción de Anja Bernardy. Revista Surco Sur, Vol. 7: Iss. 10, 40-58.

DOI: http://dx.doi.org/10.5038/2157-5231.7.10.13

Available at: https://digitalcommons.usf.edu/surcosur/vol7/iss10/14

This LA ESQUINA DEL TRADUCTOR is brought to you for free and open access by the Open Access Journals at Digital Commons @ University of South Florida. It has been accepted for inclusion in Revista Surco Sur by an authorized editor of Digital Commons @ University of South Florida. For more information, please contact digitalcommons@usf.edu. 


\section{en LA esquina DEL traduct or: Anja Bernardy*}

Lila Borrero Pierra -personaje central de Las penas de la joven Lila, novela de JoséPrats Sariol- es una emigrante a los Estados Unidos que no sólo encarna la nostalgia sino también la sensibilidad artística, la ilusión a través de su amor por Valerio, personaje que con su nombre forma una de las paradojas clave de esta novela romántica: la de no valer nada.

La intrépida Lila es cubana y poeta... "La isla ingrávida" — uno delos poemas que escribe — es un homenaje al gran escritor Virgilio Piñera, a su poema “La isla en peso", que como ningún otro texto simboliza la historia sociopolítica de Cuba en el pasado siglo xx y hasta 2016.

La excelente traducción del poema de Lila queaquí nos ofrecela Dra. Anja Bernardy -profesora en Kennesaw State University - en exclusiva para Surco Sur, es parte de su versión al inglés de la novela , que acaba de publicar la Editorial Verbum en Madrid.

* Nota del Editor

\section{José Prats Sariol}

\section{Laislaingrávida}

\section{A la memoria de Virgilio Piñera, de su poema La Isla en peso}

La deliciosa circunstancia del agua por todas partes me obliga a nadar sobre una balsa morada.

Como sé que la mar me rodea como una guirnalda duermo lirona y choteadora azul pastel. Un mirón cayó de la mata de aguacates y se partió una pata sin ideología.

Me pareció muy bien que arriesgara su vida por mi cuerpo inmortal, mientras tanto afuera, en los carnavales, sonaba la misma rumba centenaria.

Y un pordiosero negro movía el jarro pidiendo otro aguardiente de caña. Aquí nadie nunca ha vivido adánicamente, jnadie! Así que dejen la bobera esa, chicos, porque la única metamorfosis son las cucarachas alemanas que mamá nunca pudo exterminar de su cocina.

La eterna alegría que es el acto de recordar.

Yo sí formo aquellas combinaciones de maracas que devuelven cada una de las aguas, hasta la del apestoso río Quibú o Cojímar.

Para que se sepa.

Para que nadie escupa para arriba. ¿Caderas de qué, a ver las tuyas?

En la olla de los machos hierven los falos que alimentarán a las compañeras negras o blancas o mulatas en el patio de un solar lleno de tambores turísticos, de esta es Cuba dolarizada, tal vez para siempre.

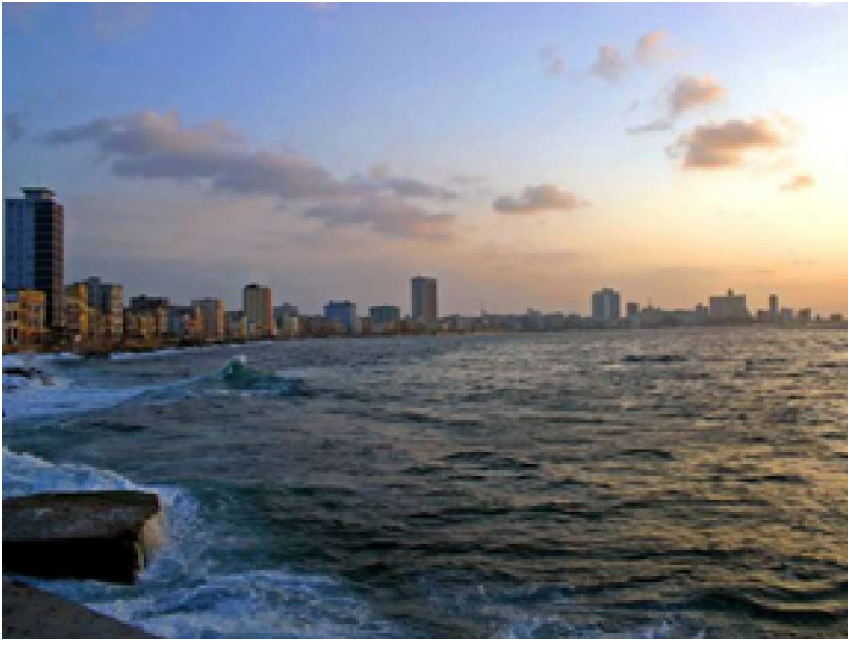


¿Oyeron el pregón?

¡Agua pa'mí, agua pa'ti, agua pa'l que le guste!...

Gocen todos el perfume de la piña que detiene a los pájaros,

a las locas balletómanas y a las zarzueleras,

a María Belén Chacón y a Chano Pozo,

y hasta a las lesbianas que compran hombreras.

Tequiero así...

Todos creemos en Dios, tú por supuesto que también.

¡N iño rebelde! ¡Gay más macho quetus bugarrones!

Las esponjas de mi baño hicieron caer al mirón,

frenéticamente,

sobre el techo dela jaula del puerco

y la escandalera y sus lamentos

me doblaron de risa.

¡Descarado!

Un aeropajita griego en Santos Suárez:

Esa es la isla ingrávida flotando entre los arrecifes coralinos,

esperando otra conga politiquera,

que se la lleve borracha hacia ninguna parte.

Salí al carnaval con mi hermano Frido, que te adora.

Compramos una perga de aguardientea granel

y esperamos la comparsa en Santa Catalina.

¿Qué pensará Santa Catalina de todo esto, te imaginas?

Pero nosotros sí nos pusimos desodorante para la conga,

y llevamos hieráticamentenuestros carnets de identidad

por si desataban la redada de los animales salvajes,

de sonar el cuero o de plan demachete o de

Unidades Militares de Ayuda a la Producción.

Por si las moscas...

Como siempreha sido, tú.

¡No te hagas!

En el desconocido son del areíto también había caciques

y algunos tenían que hacer de policías...

Recoger las yeguas y las jineteras y los pingueros

taínos o siboneyes o carabalíes o catalanes o cantoneses.

$\mathrm{Ni}$ el europeo se atreve a leer a Cartesio

cuando el timbal danza su lujuria de siempre

en el melado caos que se repite.

¡Queserepite!

Celebremos pues las mareas que nos circundan,

fronteras y escapes,

lancha de Ochún.

Virgencita de la Caridad del Cobre,

Patrona de Cuba,

¡Ayuda a tus hijos!

Flotamos a la ventura como las plumas de tus flamencos, no pesamos ni una onza, querido, ni una pestaña

en el gran concierto del mundo.

¡M étete eso en la cabeza para siempre!

Porque ni nuestros machos son los campeones incansables gozadores
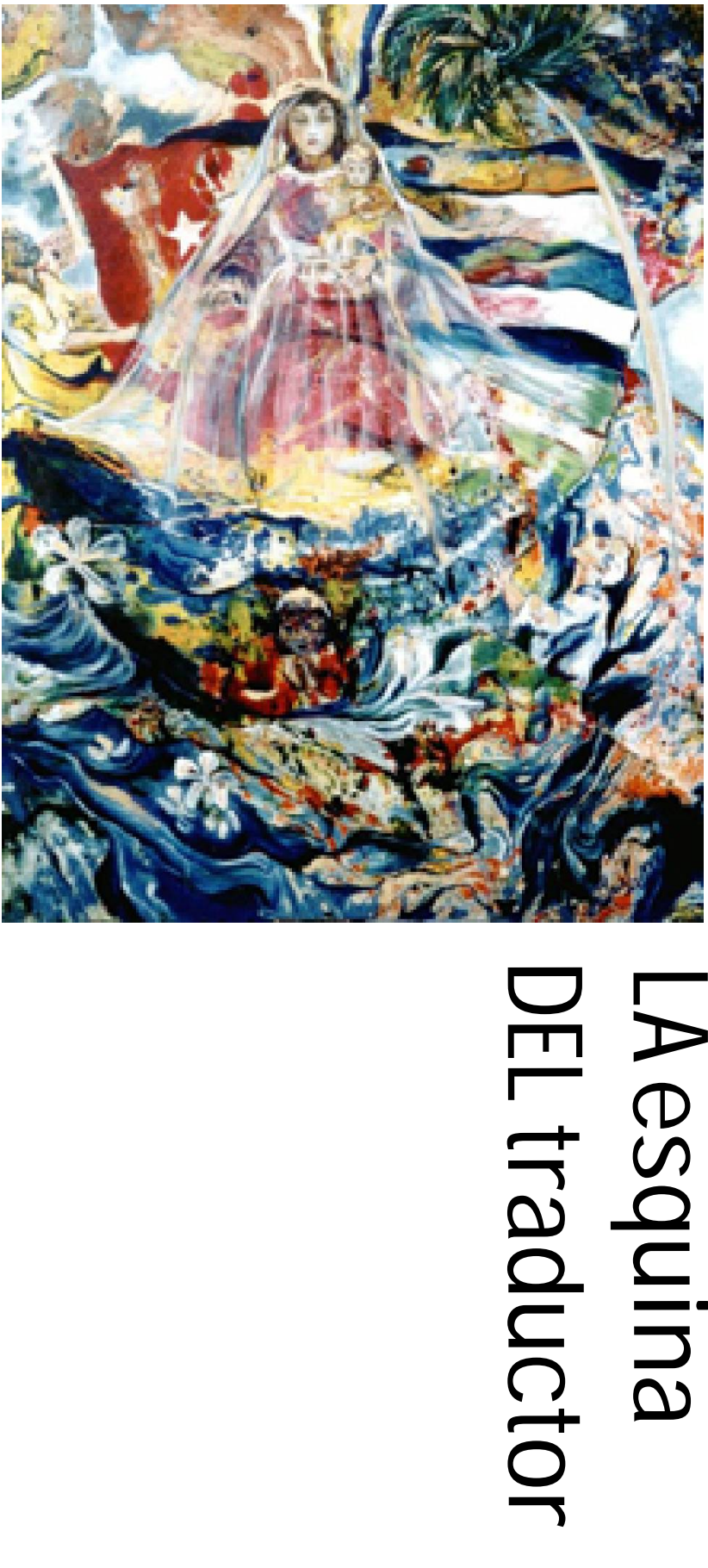
ni nuestras hembras las más sabrosonas sandungueras,

ni nuestros homosexuales los colibríes,

ni nuestras lesbianas los bomberos de la Laponia...

¡No sabemos nadar y estamos rodeados de agua!

Tan sencillo y terrible

¡País mío, tan viejo ya, y no aprendes a nadar!

Cuando aprendí a flotar me sentí dueña del universo.

A veces una ola alteraba los sosiegos del no pesar, pero yo trataba de no mover ni un pie, ni un dedo para que continuara el vaivén.

Me dejaba ir y venir y a veces abría los ojos

entre azules añil y verdes jade y amarillos centella

para saberme ingrávida,

sin que ningún peso pudiera hundirme.

Cuando aprendí a nadar practicaba los doscientos metros en una piscina. y la tercera era la de los calambres, los falta de aire, los no vale la pena.

Por eso le tengo terror a las terceras piscinas de mis competencias, porque allí se dediden los suicidios, las derrotas, los estoy tan cansada...

O se va a la cuarta, como queremos para Cuba.

Y se llega a la meta sin medallas pero con empuje

para seguir empujando el carretón.

¿Quién puede llorar cuando flota y no piensa en los ahogados,

en los mordidos por tiburones,

en los desesperados por la sed que bebieron sus propios orines,

en los balseros perpetuos que sefueron al fondo

con la única verdad de escapar?

Claro quelo sé, pero entonces ni lo presentías

y por eso cargabas la isla,

tú, tan enclenque y cabezón y procaz

y pasivo con balcón a la calle y maceticas de Diez del Día.

Así la champola de guanábana podía ser el chiste perpetuo de Cernuda:

"Sabe a semen".

O el aire en los palmares batir la guitarra

de un campo de postalitas y corona de frutas.

¡Vaya papaya! ¿No?

pero a mi madre no la picó ningún alacrán cuando estaba embarazada.

Sólo los ingrávidos podemos rér,

somos muy pocos y predominan las mujeres.

Métetelo en esa cabeza de mamey con espejuelos de notario,

asimila la nueva isla que por poco decomisa tu primera casa,

la de Guanabo, al este del Parque de la Fraternidad,

rumbo a Cárdenas donde la cigüeña te hizo posarte en 1912.

Y ni se te ocurra clasificar esto de elegía,

pues es con nombre y te olfatea en peso.

Flamboyán,

ahora Cuba usa de tu nombre como la Francia de Verlaine,

para mayor gloria de nuestro arte lógico...

¿Ya ves que es mejor flotar?

Las doncellas sabemos agitarnos,

no te preocupes,

el ciclón es también 
nuestra precariedad cotidiana, impetuosa.

Cuando lo anuncian ya sabemos

y aunque no llegue a pasar lo sufrimos en el techo,

hace temblar las cornisas y la fe.

Siempre lo hemos pintado en las cuevas de entonces

y en las cuarterías de hoy,

como abejitas obreras cuyo veneno nunca ha podido matar

a los politiqueros tan duros de pelar,

tan farola del Morro y Castillo de La Cabaña sin Tío Tom

quetocara los timbales lustrosos.

¡Sí, genuflexiones eternas!

Por lo menos las de Dios...

Pero una carcajada deja ver los dientes cariados,

las muelas que les faltan a los mayores de cuarenta

porque los mecánicos dentales no tienen con qué,

se les perdió junto a la utopía, seles desinfló

como el globo de Matías Pérez.

Genuflexiones en la Plaza de la Revolución

con retinosis y avitaminosis y el diablo colorado.

Así mismo fue, como un lechón asado relleno de moscas.

¡A plauda y mueva la banderita a la vez!

Y muchas genuflexiones porque ciertamente es costumbre, ya forma parte del valle deViñales y de lágrimas

y de las adolescentes recién púberes con los gallegos sifilíticos,

lositalianos gonorréicos, losalemanes sidosos, los portugueses alitosos.

¡Vivan las genuflexiones tan cubanas como las palmas!

Un gay de Toronto como de doscientos años enamora a Frido

en la esquina de El Floridita,

y le promete un jabón Palmolivey un perfume Avón

con tal de verlo desnudo...

¡Ah, Cuba bella, mejor quítate el peso!

O el dólar que tanto nos hicieron repudiar antes de amarlo.

Antes de la definitiva genuflexión imperialista...

Los cuerpos en la impenetrable lluvia tropical

cuyo único misterio es que no escampa nunca,

porque la llovizna - querido amigo - es con los frentes fríos

y las olas barriendo el Malecón para que los niños las cacen

semidesnudos y tiritando o titereteando como espectros

en busca del turista que les pague el perro caliente o la hamburguesa.

Jugando a la ola que no los moje, los cuerpos...

Devorándose la llovizna y derivando hacia la Corriente del Golfo,

sin luces porque las oleadas son de ir escapando.

- ¿Cómo anda la cosa?

-Escapando...

¿Ves el mambochambo?

La virginidad de la isla danza cada reconstrucción,

como los consejos de untarse al go para que el hombre no se dé cuenta,

Trotacoventos caribeña, picaresca tropical,

marañón que aprieta la bemba...

Se pierde lo quealguna vez se tuvo:

otra simpleza, hierro oxidado por el salitre,

por las resacas turbadoras o masturbadoras,

por la poesía que padece bajo el implacable sol 
la ausencia de brisa, de portales, de cobija de guano.

También por eso aprendí a nadar desde chiquita,

para que las costras de los líquenes no se me enredaran,

para huir de la orilla y de la arenas

porque aquí nadie es inocente.

Tú la sabes bien, siempre lo supiste con tus trombas,

como el poema de Oppiano Licario que el ciclón dispersó en la calle del Obispo

para que nadie nunca pudiera leerlo.

Yo tampoco tengo en la franja del iris ningún secreto amoroso,

sufro cada una de las mujeres que sufrieron la página vacía

y salieron airosas en la confusión que llamas "espantosa”,

y yo llamo leve, vaporosa, etérea

porque soy la que sólo se detiene unos instantes

en ciertas palabras tradicionales

que para mí son el aguacero pero de noche, la siesta pero junto a él,

el cañaveral pero sin contrapunteo con el tabaco.

¿Cuál es eselugar común de "verdes lujuriosos"

si la lujuria es un arcoíris cuando la ternura, cuando el cariño

sí es un son de loma y llano, de sexo sobre las hojas deálamo

para que el baile no sepa a papeleta,

para que no tengas que apagar $\mathrm{el}$ sol?

¡Bastante hiciste!

Aunqueel gallo pudo cantarte tres veces

y el rocío de la madrugada sobre las Ilanuras de Cárdenas

sólo presagiaba malabares, discriminaciones, acciones

en las azoteas apestosas o en cuarticos al quilados a la carrera

para que se te fueran los vapores.

Mi tacita de café, como la verdaderamente tuya,

nada tiene que ver con machetes y consignas

deúltima hora que volverán a ser mañana de última hora.

¡No! Los devoradores de neblina nunca se evaporan.

Valerio - el queinvento-

también puede ser un caimán o un "largo lagarto verde"

porque a mí no me importó nunca descifrarlo.

Yo lo quiero así mismo, deciénaga y de montaña,

en Yara o en New York, enfangado o entalcado.

Iba a decir cubano o finlandés...

Casi me da lo mismo mientras sea el novio y el álamo

que fabrico aquí adentro con olor a café,

a platano manzano, a rueda de aguja, a limón maduro.

¡Clemencia!

Nola merecemos.

Por lo menos ustedes no sela merecen...

Nosotras tal vez porque mientras cortaban caña,

que también la cortamos,

era el anafre y los carbones del ajiaco,

el almidón para rociar la plancha,

las zurcideras con el quinqué y el niño col gado de la teta.

¿Clemencia no sellamaba la mujer de Pedro Páramo?

$Y$ eso que el sustantivo faena es tan cubano como la flor nacional:

la mariposa quecruzó desde la India como tus cañas tristes.

Porque además no hay hora fija para la tristeza,

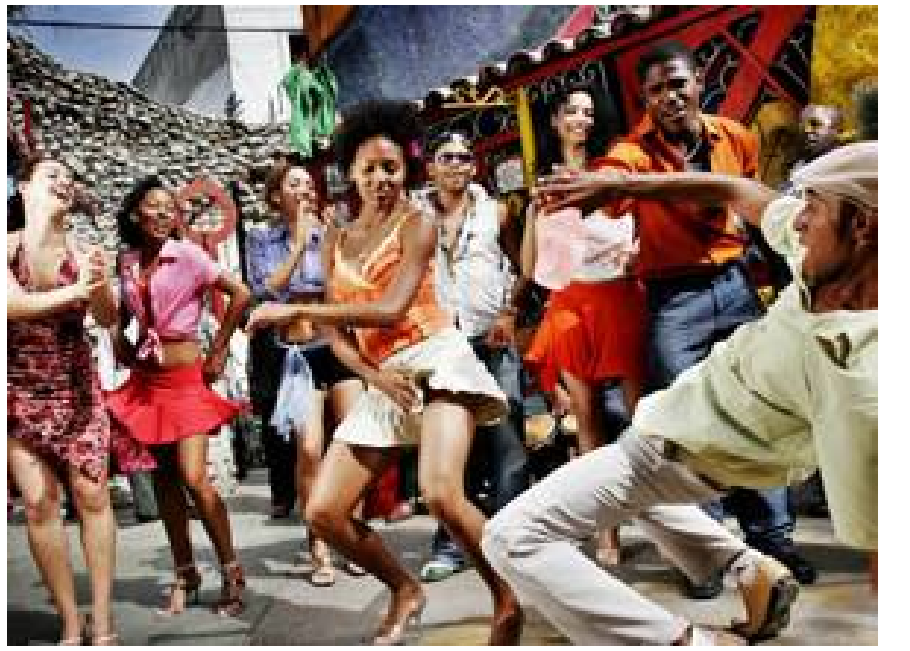


lo supe tempranito en Ia Iglesia de los Pasionistas,

frente a la Calzada de Jesús del Monte que ahora se llama 10 de Octubre, aunque a Eliseo Diego nunca le gustó ese cambio.

Rezaba por los nacidos en esta Isla ingrávida

y ahora en cada iglesia vuelvo a estar en el mismo reclinatorio, con el neogótico quiquirimiau del órgano que sigue desafinado, con los vitrales por cuyos huecos entran los gorriones para anidar detrás del altar mayor.

Mi piel no tiene hora, ni sol ni luna ni espejuelos oscuros.

Nunca he querido escapar de ella porque no me da la gana, porque nací después del juego y por lo tanto desconozco sus reglas, sus renegados, sus adictos. Las leyendas pasaron por mi piel sin dejar huellas.

Las pieles curtidas huelen mal, se sabe que huelen a sal de tenerías manzanilleras. Pero la piel de la Isla

- si existiera-

debe ser un mito más.

La piel cubana llora a sus ahogados, a los que nunca entendieron que nadar no era un deporte más.

Por eso tiene escamas como las sirenas

y es verdinegra y a veces hiere como los erizos

o se vuelve tan rugosa como una estrella de mar.

A unque por lo general la veo como las aguas malas, celentéreos gelatinosos casi violetas que flotan

para que te den deseos de agarrarlos,

para que las quemaduras no se te olviden mientras vivas.

La piel que nunca más será criollista,

ni entrará al teatro vernáculo vestida de novia.

La piel cubanísima que desde el gallinero aplaudirá

la danza desnuda de los sin pieles,

el cotorreo de los sin cuerdas vocales.

Hasta que me pueda untar una crema solar

y tenderme en Santa María o en Guanabo

sin que me confundan con una turista.

Hasta que esta piel amelocotonada

quiebre las migraciones como si fuera una calavera.

La piel...

¡M anda Cuba esto!

¡N o hay que tapar nada!

Dejemos que la claridad avance y descubra cada resquicio de nosotros,

sin melado ni anones, sin prontuarios de lo cubano.

Dejémonos de sanacadas

y abramos el baúl de Pandora o de Cecilia Valdés.

Paquito de Rivera tocará su saxofón

en un jazz libre de fronteras y vinos agrios

porque - como se sabe - no tenemos viñedos

y las iras van a flotar,

te lo digo yo, a rumbear detrás del Alacrán

como en los días de reyes cuando autorizaban a los negros

a que sus ritos inundaran la Plaza de la Catedral.

Sí, es verdad que no tenemos secretos...

La bola o el chisme mandan al Colegio de Francia la teoría del rumor.

Mis dos viejas vecinas inventaron la teoría de la persiana, 
la patentizaron a las doce del día, rayando el plomo del sol.

Gracias a Dios que no eran miembros del Comité de Defensa de la Revolución.

Nereida y Flora, la de pies grandes y tacón jorobado,

ejercían en la bodega y en la carnicería, en la cola que fuera,

siempre claras y exactas ampliando el eco.

Una por una, uno por uno, recordándolo todo tan clarito

como el café de la cuota racionada que sabía a chícharos, a sopa de quimbombó.

La claridad de Nereida armando la noticia

y la de Flora encargada de la expansión

son el mejor secreto de mi barrio:

su exacta cubanidad diligente.

A ellas dos debemos la claridad, no a las doce del día,

no a ese sol que ciega blanquecino

y mata de luz sudorosa, de luz pegajosa, de luz axilas.

Pero nuestro mediodía también flota ingrávido sobre las aguas convulsas.

Ayer fue la pesadilla de vivirlo en una parada de guagua,

iba para la universidad y la 37 padeáa una abstemia totalitaria y futurista.

A la una y media regresé para la casa,

a bañarme de nuevo.

Flota, claro que sabeflotar porquesi no hubiera desaparecido hace siglos.

Mediodía deaire acondicionado que se sueña remoto o terremoto,

mediodía de limonada helada que se sabe espejismo sahariano,

mediodía de iglú con esquimal y foca que no sale ni en el Noticiero de la TV,

mediodía enumerativo que sin embargo nunca desaparece del espectro

como un rabo de nube o como la nueva trova.

¡Flota!

Me está flotando ahora mismo.

La siesta del fauno o del chivo rueda las cortinas de guinga

que mamá cosió para la ventana de mi cuarto.

Después de almuerzo dicen que con un solo pelotón

se pueden adueñar de La Habana.

El enemigo acecha, pero si son cubanos no hay peligro,

dormitan igualiticos que los supuestos contrincantes

y a la misma hora descabezan o roncan el potaje.

A lo mejor se pelearon porque a uno se le ocurrió prohibir la siesta.

Vaya usted a saber,

pero como somos durmientes armaremos una tregua

hasta que la tarde deshaga entre nubes las lenguas broncas

delos eternos fundamentalistas inmóviles, egipcios.

Y se haga obligatorio aprender a nadar

porque el corcho dela Isla - pueblo mío-

esimposible desacar.

Yo debo tener algún ascendente canario:

ladro y aúllo y me burlo de cada mediodía,

soy tan isleña que me da pena y se me cae la cara de vergüenza

cuando me preguntan y proclamo cubana sin palmas,

cubana a tiempo completo pero libre de guantanameras.

Cuando pongo un CD de Celia Cruz o del Benny Moré

el guaguancó llega por dentro, envolvente,

hasta el mismo Miguel Matamoros se asombraría...

Así que entonces qué, ¿a ver?

La yuca con mojo que preparamos aquí en casa de Virginia

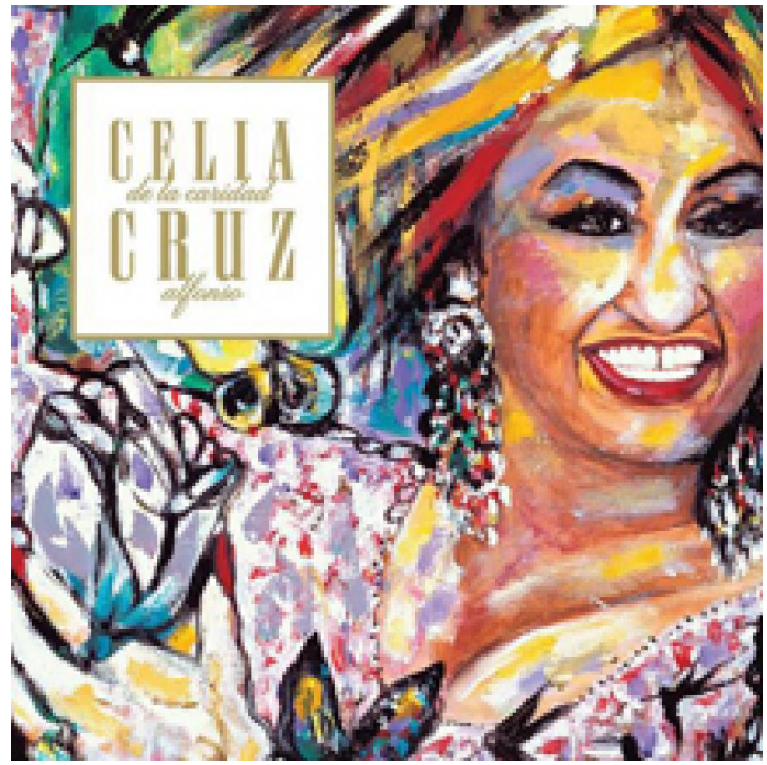


sabe igual que la de allá, a veces mejor o peor, a veces con hebras de nostal gia pero

qué rico y sabroso bailan el mambo las emigradas...

Mis hojas de yagruma están secas en el florero de la vitrina, los domingos después del mediodía quizás les tiro un golpe de vista. Sacudo la cabeza y sigo... y sigo hasta el espejo para saberme despierta, sin trances pesados, sin arrobas pasadas. Pasados por agua, porque no engordan...

Por lo tanto a la ducha y a pesarme desnuda contra la adiposis, a componer la tarde con A madeus en el columpio del jardín y con unas empanadillas de guayaba con queso amarillo, de las que podría comerme veinticinco si no fuera por la dieta quela joven profesora de español cumple porque se quiere para querer mejor, porque legusta la ropa ajustada y su bikini blanco, y hasta las miradas de los bestias cuando se pierden detrás de una, enloquecidosy pueriles, remachistas leninistas.

Vox populi, vox Dej:

- Si cocinas como caminas me como hasta la raspita.

- Mami, me vas a matar.

- Así mismito mela recetó el médico.

-Me rindo, ganaste, pide por esa boca.

- ¿Usted lo hace a propósito, verdad?

-Tómemela presión para que vea.

- Lejuro que no se me ocurre ningún piropo...

Una guinea chilla, ¿chillan las guineas?

El guineo sí, daro, las tardes de domingo.

Purgatorio de la autolástima aburrida, del socotroco.

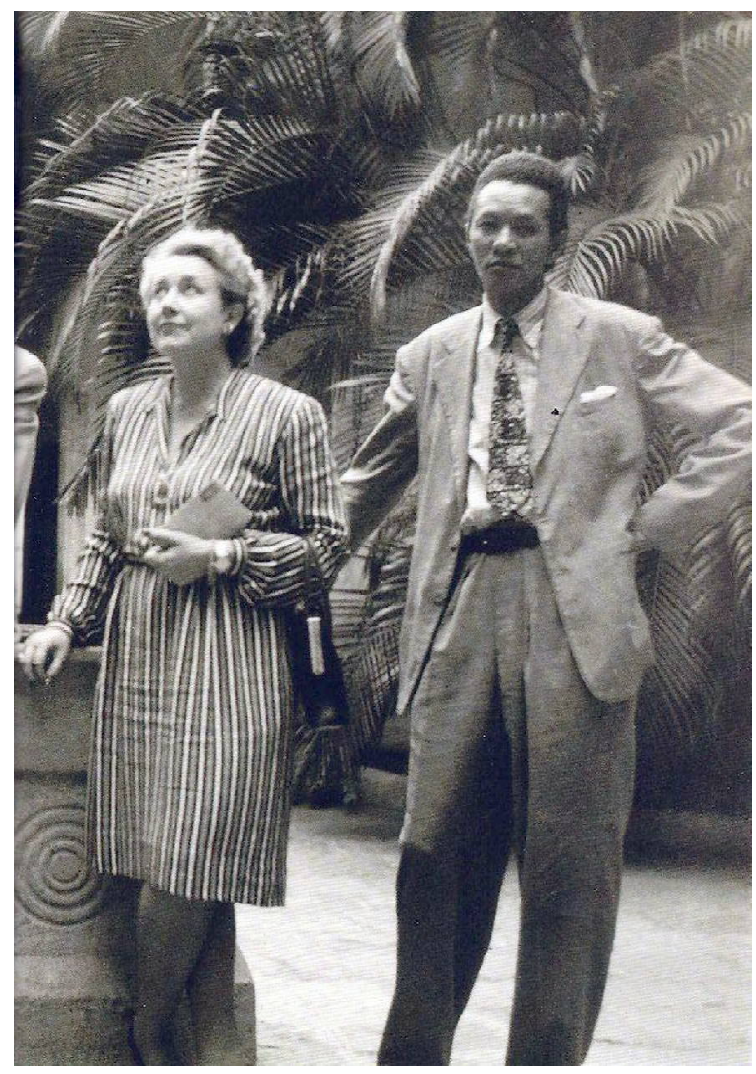

Como sé nadar mi latín son los sagaces versos de Catulo meciéndome en el sillón, convertida en su Clodia ardientey cruel y casquivana.

Como nado de espal das puedo ver la pareja en Roma o en Santiago de Las Vegas, imaginar que Valerio me los lee en el Jardín Botánico, antes, durante y después de ponernos a jugar a los animalitos, en el medio de alguna picardía que me suelta las clodias.

Y como nado pecho y mariposa la poesía puede esperar la noche sin temores prosaístas ni exteriorismos vacuos, sin pornografías de las que aburridamente hunden el dítoris en la venganza congelada -feministas con huecos.

¡Puedo nadar hacia la noche!

A mí nada seme esfuma...

Séqueen mi isla setiende a desaparecer, por eso mismo cuando me zambullo tomo aire suficiente para el ascenso.

Braceo con fuerza, dueña de las aletas de mi nariz y de los peces.

Sélo que arriesgo.

Y como también sélo que no somos, meburlo delos resúmenes flatulentos de investigadores por supuesto que más flatulentos.

La batuta la lleva no la noche sino una duda del tamaño del Capitolio. Una duda que puede tocar el güiro sin irse de pachanga, apretarseentre los bailadoresy no mover los pies, ser pareja de un apuesto axioma y burlarse a la vez de su bigote. Una duda que en la noche va, como en el bolero. 
Y que no duerme la madrugada porque no está cansada,

porque sigue de anfitriona a lo que llegue,

como la bienvenida que siempre hemos sido,

unas veces por suerte y las más por desgracia,

pero con la puerta entreabierta con el gancho y las ventanas de par en par.

¡Viva la noche cubana!

Interrumpida por los indios, las Españas y A fricas y Chinas

porque nadie es del Caribe y aquí doblan las corrientes.

¡Gracias a Dios que antillana, huracanada,

de la mar siempre mujer, serena o peligrosa!

Noche del lleva y trae, de entre y sale, de caldero revuelto.

De las excrecencias también, y del béisbol.

¿Por qué no?

Suspiremos sin peso y resignémonos antes de aplaudirnos.

No importa lo que vaya delante de los tambores y la trompeta,

sigamos la palabra más conocida, la rumba sin rumbo.

A mén y noche.

¿Quién te ha dicho que todos quieren copular?

¿De dónde sacaste tamaña guanajada noctámbula?

¿Será otra mascarada de las tuyas?

¿O tal vez tu Madame Bovary de que así sea?

¿A ver? ¿Y en Gran Bretaña o en Tímor no pueden copular más y mejor?

¡Sobobo!

-En eso sí hay que decirnos usted...

-A la verdad que somos los bárbaros...

A unque dos cuerpos en el platanal valgan tanto como Adán y Eva

y el amparo de los amantes sea el primer deber,

aunque la androginia sea como la lotería primitiva:

seis números cel estiales, fiesta del infeliz.

A unque nadie sea agnóstico cuando le descubren una enfermedad incurable,

cuando espera siete días que una playa lo encuentre,

cuando no tiene qué echarle a la sopa...

Aunque podamos bañarnos de noche,

fuera de la realidad y con deseos desnudos.

A unque se te caiga de la cartera el resguardo

en medio de una reunión

y nadie se atreva a recogerla del piso por si acaso.

A unque cuando la lluvia nos arrasa le pidamos a Yemayá que cese,

y cuando se pierde el anillo recemos la oración de San Gonzalo...

¿Así que con el cuento de agnosticismo existencial?

¿Quién te lo va a creer en la Isla?

Cierto que un pueblo se hace y se deshace

pero quedo flotando porque apenas cargo

tres obsesiones (A madeus, padecer de nostalgia, encontrar a Valerio),

cuatro ideas y media (Sí, no, sí, no, tal vez),

seis sabores de frutas( caimito, anón, marañón, piña, mamey, hicaco),

siete sitios (Debajo de un álamo del Jardín Botánico en el sureste habanero)

y un verso anónimo con una sola palabra que Colón quiso entender como "Gran Khan" y era "Cubanacán" — centro de Cuba...

Bajo la lluvia me estoy bañando en la mar sobre la estrella

de un milenio que no quiere nacer bajo los guateques de una historia fardo, de una historia rendición de cuentas, de una historia debajo. 
Floto y nado mi historia que no puede pesar, apesadumbrar porque como bien se sabe está rodeada de aguas por todas partes,

y es de avanzar sin deudas

- como de verdad querían los héroes y mártires

pues de lo contrario no serían verdaderos héroes y mártires.

Una historia tan yo como sin masa,

tan sin poder como sin tiburones...

Al menos así la sueño nadando estilo libre,

en el mismo amor de un pueblo sin peso.

The weightless island

To the memory of Virgilio Piñera, to his poem La Isla en peso

The delicious circumstance of water everywhere

forces me to swim on a purple death raft.

Since I know that the sea surrounds me like a garland,

in the pastel bluel lay sleeping, joking.

A voyeur fell from the avocado tree

and without any ideology, he brokea leg.

I thought it was fine for him to risk his life for my immortal body,

while outside, at the carnival,

the same millennial party was going on.

And a black beggar was shaking his jar

begging for some more sugarcane aguardiente.

No one around here has ever had an idyllic life, no one!

So stop this nonsense, boys,

because the only metamorphosis are the German cockroaches

that Mom could never exterminate from her kitchen.

Eternal happiness is the act of remembering.

I do think of those maraca combinations

that make the waters of time flow back to me,

even those of the stinking Quibú or Cojímar river.

So that everyone knows.

So that no one spits into the sky.

What kind of hips? Let me see yours.

In the male cauldron the phalluses boil.

They will feed our black or white or mulatto sisters

in the courtyard of the tenement where tourists listen to drums

-this is the dollar in Cuba, maybe forever.

Did you hear the announcement?

Water for me, water for you, water for everyone...

Enjoy the scent of the pineapple that attracts the birds,

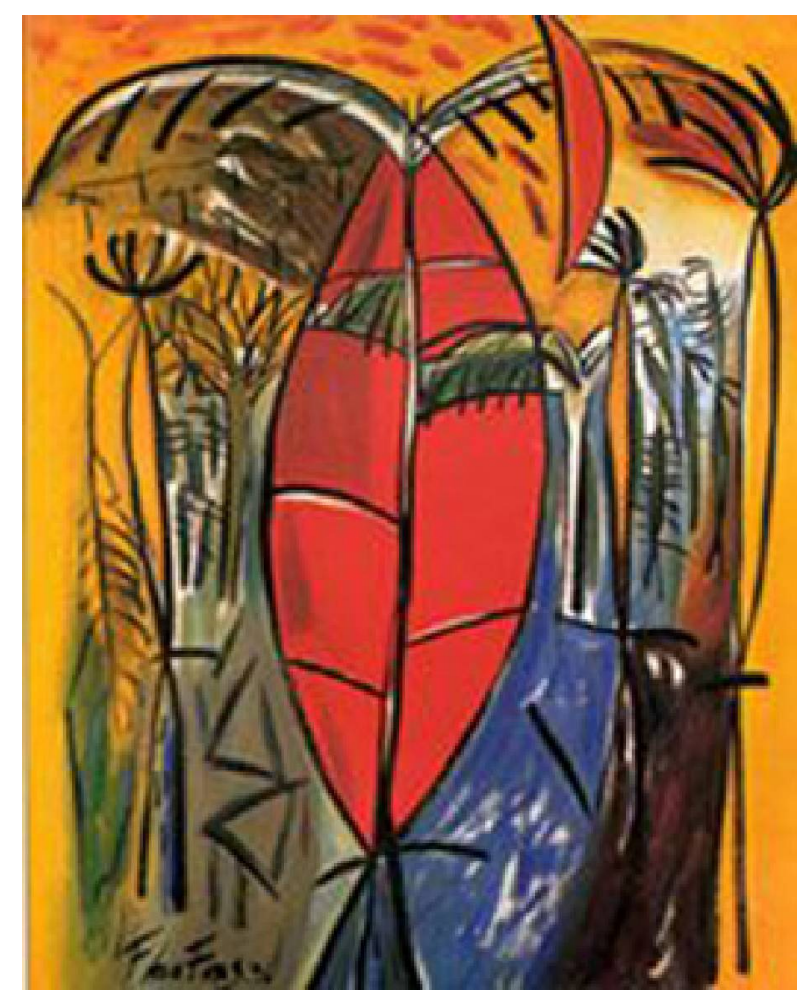

the local queens who love ballet and zarzuelas,

María Belén Chacón and Chano Pozo,

and even the lesbians that buy shoulder pads.

That's how I love you...

Weall believe in God, and you do too, of course.

Rebel child! A gay more manly than your buggerers!

The sponges in my bathroom made the voyeur fall,

frantically,

on the roof of the pig sty. 
The commotion and his outcries

made me laugh my head off.

How shameless!

A Greek jacking off in Santos Suárez,

that is the weightless island floating between the coral reefs,

waiting for another conga of demagogues

to take her away to nowhere, drunk.

I went to the carnival with my brother Frido, who adores you.

We bought a cup of aguardiente from the barrel

and we waited for the dance troupe in Santa Catalina.

What do you think Saint Catalina would make of all this?

But we did put on some deodorant to participate in the conga

and expressionless, we took our national ID cards

in case they were planning to round up the wild animals,

or if there was a bugle call or if they started hitting us with their machetes

or if Military Units to Aid Production showed up.

Just in case...

You! It is as it has always been.

Don't pretend!

In the unknown rhythm of the areito there were chiefs as well

and some had to act as the police...

Rounding up the mares in heat and the whores and the male prostitutes,

Tainos or Siboneys or Calabarians or Catalonians or Cantonese.

Not even the Europeans dare to read Descartes

when the drum dances its usual lechery

in this sweet and sticky chaos that is repeated

and repeated again.

So let's celebrate the tides that surround us,

frontiers and escapes,

Ochún's boat.

Our Lady of Charity,

Patron Saint of Cuba,

please help your children!

We drift at large like the feathers of your flamencos,

we don't weigh even an ounce, my dear, not even an eyelash

in the grand concert of the world.

Get that into your head once and for all!

Because our males are neither tireless champions

reveling in pleasure,

nor our females the most delicious of women,

nor our gays hummingbirds,

nor our lesbians the fire fighters of Laponia...

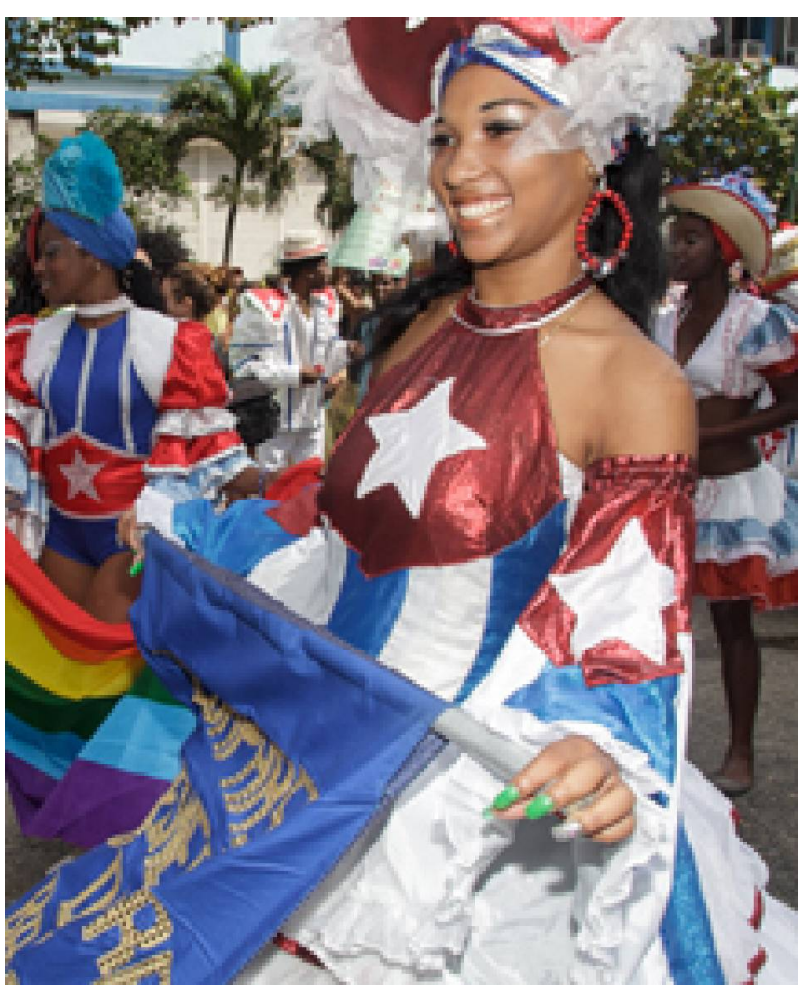

We don't know how to swim and we are surrounded by water!

It's that simple and terrible:

$\times{ }^{M}$

When I learned how to float I felt likel owned the universe.

Sometimes a wave would alter the calmness of being weightless,

but I would try not to move onefoot, not even onefinger,

so I could continue drifting in the waves.

I would let myself go back and forth and sometimes I would open my eyes 
between indigo blues and jade green and brilliant yellow

so I could feel weightless,

so that nothing could weigh me down.

When I learned to swim I would practice doing two hundred meters in a pool

and by the third lap I would get cramps, be out of breath, and almost give up.

That's why I fear getting to the third lap in my competitions,

because that is where we decide suicides, defeats, the "I'm-so-tireds"...

Or you go on to the fourth, that's what we want for Cuba.

And you make it to the finish line without medals but with enough energy

to continue pushing the cart.

How can you cry when you're floating and not thinking about those who drowned, about those who got bitten by sharks,

about those who were so thirsty they drank their own urine,

about those perpetual rafters who went to the bottom

taking with them their desire to escape?

Of course I know it, but back then you didn't even have a due

and that's why you carried the island,

you, so weak, so pigheaded, so daring

so obviously quer,

like a front-facing balcony and flower pots with Kiss Me Quicks.

That's how the soursop shake could be Cernuda's permanent joke:

"It tastes like semen."

And the wind rustling in the palm grove could play the guitar

on postcards of the country side with crowns made of fruit.

Don't you just love papaya? Yum!

But my mother wasn't stung by a scorpion when she was pregnant.

Only the weightless can laugh,

there are very few of us and we aremostly women.

Get it into your cone head with those notary spectacles,

assimilate the new island that almost seized your first home,

the one in Guanabo, east of Fraternity Park,

on the way to Cárdenas, where the stork deposited you in 1912.

And don't think you can dassify this as an elegy,

because the poem has a name and can smell your weight.

Flamboyant,

now Cuba uses your name like France does Verlaine,

to exalt our logical art...

Do you see now that it is better to float?

Maidens know how to shake things up.

Don't worry,

the cydone is also

our everyday, impetuous precariousness.

When they announce it we'll al ready know

and even though it might not happen we feel it on the roof,

it rattles the cornices and our faith.

We have always painted it in the ancient caves

and in today's tenement housing,

like worker bees whose venom has never been able to kill

the politicians that are hard to pel,

as Cuban as the lighthouse at El Morro and the Castillo de la Cabaña without

UndeTom 
playing the shiny timbales.

Yes, eternal genuflections!

At least the ones for God...

But it just takes a good laugh for everyone to see the decayed teeth,

themissing molars if you're over forty

because the dental mechanics don't have the tools,

they got lost along with utopia, deflated

like Matías Pérez' hot air balloon.

Genuflecting on Revolution Plaza

with retinosis, hypovitaminosis, and the red devil.

That's how it was, like a roast suckling pig stuffed with flies.

Clap your hands and waive your little flag at the same time!

And lots of genuflecting because that is certainly the custom,

it is part of the valley of Viñales and the valley of tears

and part of pubescent adolescents who met the Spaniards with syphilis,

the Italians with gonorrhea, the Germans with AIDS, the Portuguese with halitosis.

Long live genuflections, as Cuban as the Cuban palm!

A gay from Toronto, about 200 years old, tried to pick up Frido

on the corner of El Floridita,

and he promised him Palmolive soap and Avon perfume

as long as he could see him naked...

Oh, precious Cuba, you better get rid of your peso!

Or the dollar that they made us loathe before weall loved it.

Before the final, imperialist genuflection...

The bodies in the impenetrable tropical rain

whose only mystery is that it never ends,

because the drizzle - dear friend- comes with the cold fronts

and the waves that sweep the Malecón so that children can try to catch them,

half-naked and shivering or shaking like ghosts

looking for a tourist who will pay for their hot dog or hamburger.

Playing with the wave, daring it to get them wet, the bodies...

Getting soaking wet and being pulled into the Gulf Stream,

without any lights because the waves are for escaping.

"How's it going?"

"Escaping..."

That's how the mambo goes.

The island's virginity dances every reconstruction,

like the advise to trick a man into believing you're still a virgin,

a Caribbean Celestina, a tropical picaresque novel,

a cashew fruit so tart it makes you pucker your lips...

You lose what you had at one point:

a different kind of simplicity, iron oxidized by the salt water,

by the turbulent or masturbulent undertow,

by the poetry that under a relentless sun suffers

the absence of breeze, of porches, of a palm frond shelter.

That's another reason I learned to swim when I was young,

to avoid becoming entangled in the lichen leaves,

to get away from the shore and the sand

because here no one is innocent.

You know it well, you have always known it with your whirlwinds,

like Oppiano Licario's poem that the cydone dispersed on Obispo Street

so that no one could ever read it. 
I don't keep any love secrets in my sights either,

I suffer like every one of those women who suffered every blank page

and turned out victorious in this confusion that you call "awful,"

and which I call light, diaphanous, ethereal,

because I consider certain traditional words

only for a few moments.

For me they are the downpour, but at night, a nap, but next to him,

sugarcane fields, but without the contrast of tobacco.

What is that cliché about "lush greens"?

With tenderness, with affection, lust is a rainbow, a song of hills and prairies, of sex atop the poplar leaves, so you can enjoy the dance without having to pay for it,

so you don't have to extinguish the sun.

You have done enough!

Although the rooster crowed three times

and the morning dew on the plains of Cárdenas

only forewarned of circus acts, discrimination, and sex

on a stinky rooftop terrace or in a room rented in a hurry

to dissipate the vapors.

My cup of coffee, as the one that's truly yours, has nothing to do with machetes and the latest slogans that tomorrow will be the latest once again. No! Those who devour the fog never disappear.

Valerio-the one I'm inventing-

could also be an alligator or a "long, green lizard"

because I never minded having to figure him out.

I lovehim just the same, whether he comes

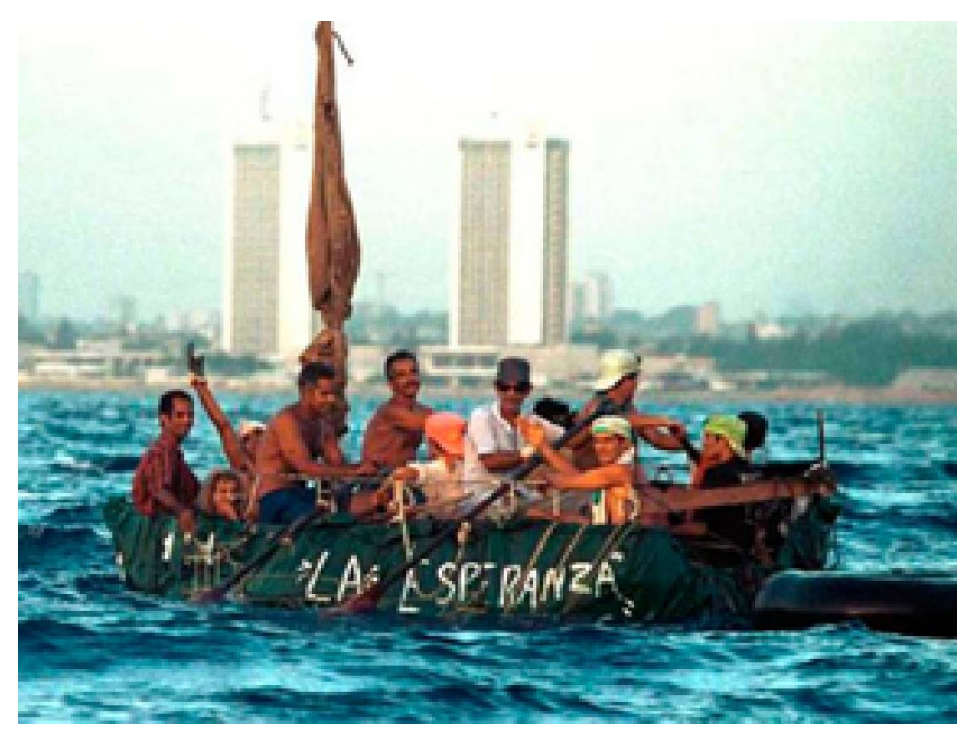

from the marsh or the mountain,

lives in Yara or in New York,

is covered in mud or in talcum powder.

I was going to say whether he is Cuban or Finnish...

I almost don't care as long as he is my boyfriend (and the poplar

that I'm creating inside), and he smells of coffee,

Manzano bananas, swordfish steak, ripe lime.

Clemency!

Wedon't deserveit.

At least you guys don't deserveit...

Maybe we do because while you cut sugar cane,

something women also do,

we took care of the hearth and the coals for the stew,

starching and ironing clothes,

mending them by the light of an oil lamp as the children hung on our breasts.

Clemency-wasn't that the name of Pedro Páramo's wife?

And you have to consider that the noun "Iabor" is as Cuban as the national flower,

the butterfly lily that came over from India as Cuban as your sad sugarcane.

Anyway, there isn't a set time for sadness either,

I knew that early on from the Church of the Passionists of Christ,

on Jesús del Monte Avenue, which is now named 10th of October,

even if Eliseo Diego never liked that change.

Hewould pray for those born on this weightless Island

and now I go back to kneeling on the prayer bench in every church

with the neo-gothic cockadoodlemiau organ that is always out of tune, 
with the stained glass windows that let the pigeons in through the holes

so they can nest behind the main altar.

My skin doesn't have a set time, neither solar nor lunar,

nor does it need dark shades.

I have never wanted to crawl out of it

because I don't feel like it, because I was born after the game started

and that's why I'm not familiar with the rules, the renegades, the addicts.

Thelegends passed over my skin without leaving a trace.

Their oil-tanned hides stink, the salt used in the process

makes them smell likethe tanneries

in Manzanillo.

But the skin of the Island

-if it existed-

is probably just another myth.

Our Cuban skin cries for those who drowned,

for those who never understood that swimming wasn't just another sport.

That's why it has scales like mermaids do and it's greenish-black

and sometimes inflicts pain like a sea urchin's spines,

or it becomes as rough as a starfish.

Though for the most part I consider it to belike jellyfish,

gelatinous coelenterates of purple color.

They float to make you want to catch them,

so you never forget the pain of the stings as long as you live.

Cuba's skin will never again be like it used to be

nor will it enter the vernacular theater dressed as a bride

That typical skin that from the gallery applauds

the naked dance of those without skin,

the chatter of those without vocal cords.

Until I can put on some sunscreen

and lay on the beaches of Santa María or Guanabo

without being mistaken for a tourist.

Until this peach-colored skin

shatters the migrations as if they were a skull.

Skin...

To hell with Cuba!

Nothing should be covered up!

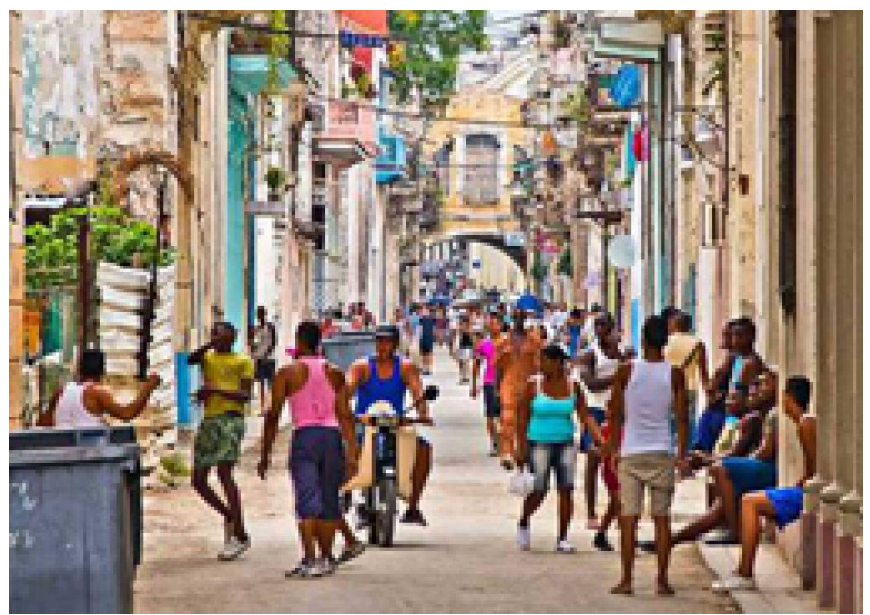

Let clarity advance and let it find its way in through every small crack in us,

without cane syrup or anon fruit, without instructions on how to be Cuban.

Let's quit being stupid

and let's open Pandora's box or the one belonging to Cecilia Valdés.

Paquito de Rivera will play the saxophone,

a jazz free of borders and sour wines

because - as you know - we don't have vineyards,

and anger will drift away.

I'm telling you, let's join in with the Scorpion dance troupe

like in the days of the kings, when they allowed blacks

to flood the Plaza of the Cathedral with their rhythms.

Yes, it's true that we have no secrets...

Rumors or gossip send the theory of hearsay to study at the Collège deFrance.

My neighbors, two old ladies, invented the theory of the blinds,

they patented it at twelve o'dock noon, in the heat of the day.

Thank God they weren't members of the Committee for the Defense of the Revolution.

Nereida and Flora, with their big feet and broken heals,

practiced at the store and at the butcher's, waiting in whatever line, 
always dear and precise, amplifying the echo.

One at a time, one by one, remembering everything with great darity,

as dear as the coffee from our ration that tasted like dried peas, like okra soup.

Theclarity of Nereida telling the story

and Flora in charge of embellishing it

- that is the best kept secret in the barrio-

it has that exact Cuban diligence.

We owe the darity to them, not to the noonday light,

not to that unforgiving sun that blinds you

and kills you with its sweaty, sticky, smelly armpit light.

But our noon also floats weightlessly in the convulsing waters.

I lived that nightmareyesterday at the bus stop,

I was going to the university but bus number 37

suffered a totalitarian and and futuristic abstinence.

At half past onel went home

to take another shower.

It floats, of course it can float because if it didn't, it would have disappeared

centuries ago.

Noontime with the air conditioning on,

a remote dream,

noontime with an ice-cold lemonade that you know is a Saharan mirage,

noontime in the igloo with an Eskimo and a seal that don't even appear in the news on TV,

noontime without end, it al ways remains part of the spectrum,

no matter what,

like the tail of a cloud or the new Trova.

Itfloats!

Like a floater in my eye.

The faun's or the goat's nap draws the gingham curtains

that Mom sewed for the windows in my room.

They say that after lunch a single squad

could take over Havana.

The enemy is waiting to attack, but there's no danger if they're Cuban,

because they're snoozing and snoring at the very same time

as their supposed opponents, sleeping off their meal.

Maybe they got into a fight because one of them wanted to prohibit taking naps.

Who knows how it happened,

but since we love to sleep we will agree on a truce

until between the clouds the afternoon unleashes the combative tongues

of the eternal fundamentalists who remain motionless, like the Egyptians,

until learning how to swim becomes mandatory,

because the cork of the Island-my people-

is impossibleto get out.

I must have some Canarian blood in me:

I bark and howl and make fun of every noon.

The island is so much a part of methat it hurts and I get embarrassed

when they ask me and I have to say I'm Cuban, but without the palm trees,

a full-time Cuban but without melodramas.

When I listen to a CD by Celia Cruz or Benny Moré,

the guaguancó comes from the inside and envelops me,

even Miguel Matamoros himself would be surprised...

So then what? Let's see!

The yucca with garlic sauce that we prepare here at Virginia's

tastes the same as the one over there, sometimes better, sometimes worse, 
sometimes it has strings of nostalgia but

these exiles sure know how to dance the mambo...

I keep my dried yagruma leaves in the vase on the China cabinet,

on Sunday afternoons I might take a look at them.

I shake my head and I continue... I continue to the mirror

to make sure I'm awake, without any heavy trances, without any extra weight.

Like a soft-boiled egg, because prepared that way they don't make you gain weight...

So, to fend off obesity, I need to take a shower and weigh myself naked,

spend the afternoon with Amadeus on the swings in the backyard,

eat some guava empanadas with yellow cheese,

the kind I could eat twenty-five of in one sitting if it weren't for my diet,

the one the Spanish professor sticks to

because she has to love herself so she can love better,

because shelikes well-fitting clothes and her white bikini,

and even the looks from those beasts when they follow her with their eyes.

It drives those childish, ultra-chauvinist Leninists crazy.

Vox populi, vox Dei:

"If you cook the way you walk, I'll even scrape the pan."

"Baby, you're gonna kill me."

"You're just what the doctor ordered."

"I give up, you win, you can have whatever you want."

"You do this on purpose, don't you?"

"I'm not kidding, check my blood pressure."

"I swear, you leave me speechless..."

A guinea hen screams, do guinea hens scream?

The guinea cock for sure, on Sunday afternoons, of course.

Purgatory made of boring, stubborn self-pity.

Since I know how to swim, my Latin is the clever poems of Catullus

rocking me in my rocking chair.

I have turned into his ravenous Clodia, cruel and indifferent.

Since I'm doing the backstroke, I can see the couple in Rome

or in Santiago de Las Vegas,

I imagine Valerio reading the poems to me in the Botanic Garden,

before, during, and after we play at being animals,

in the midst of being naughty, which brings out the Clodia in me.

And since I do both breaststroke and butterfly, poetry can wait until tonight

without having to fear the prose writers nor the frivolous exteriorism,

without the kind of boring pornography that drowns the clitoris

in a frozen vengeance - feminists with holes.

I can swim into the night!

Nothing escapes me...

I know that on my island people tend to disappear,

that is why before jumping in I take in enough air to come back up.

My strokes are strong, I am in control of my nasal wings and of the fish.

I know what I'm risking.

And sincel also know what we are not,

I make fun of the flatulent summaries given by academics, who

of course are even more flatulent.

The night is not in charge, doubts the size of the Capitol are.

Doubts that can play the güiro without going to the party,

squeeze in among the dancers without moving their feet,

partner with a handsome axiom and mock his mustache at the same time. 


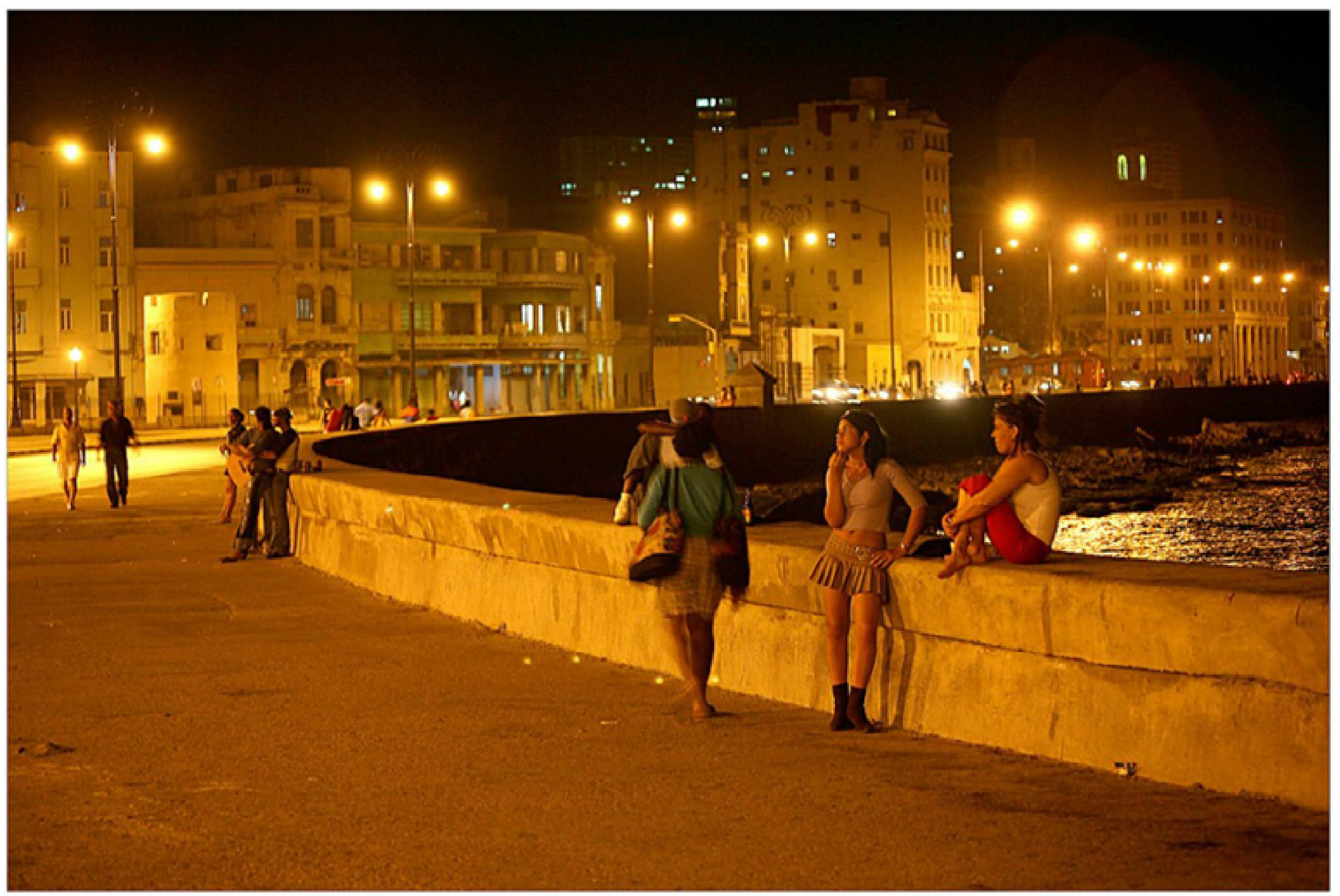

Doubts that move through the night, like in the lyrics of a bolero.

And they don't sleep at night because they're not tired, because they play host to whatever, to whoever comes along,

like the welcome that we have always been, sometimes out of luck and more often out of misfortune, but with the door ajar, propped open by the door stop and the windows open all the way.

Long live the Cuban night!

Interrupted by the Indians, the Spains and the Africas and the Chinas because no one is from the Caribbean and the Gulf Stream splits here. Thank God that she is Antillean, tempestuous, from the sea, always a woman, serene or dangerous.

A night of coming and going, of entering and exiting, of burning bodies. Of excrescences as well, and baseball.

Why not?

Let's sigh without the weight and resign ourselves before applauding.

It doesn't matter who leads the drums and the trumpets,

let's follow the words of the leaders, wherever the rumba takes us.

Amen and good night.

Who told you that everyone wants to copulate?

Where do you get a nocturnal stupidity of that size?

Is that another one of your masquerades?

Or maybe your Madame Bovary told you that's how it should be?

Let's see. Don't they copulate more and better in Great Britain or in Timor?

You areso dumb! 
"It don't get no better than this..."

"Stick with me and you'll see..."

Even though two bodies in the plantain fields are worth as much as Adam and Eve

and protecting each other is the lovers' primary duty,

even though androgyny is like the primitive lottery:

six celestial numbers, a poor man's celebration.

Even though no one is an agnostic when diagnosed with an incurable disease,

when you wait seven days for a beach to find you,

when you don't have anything to put in the soup...

Even though we are able to swim at night,

removed from reality and with naked desire.

Even though you accidentally drop your amulet

in the middle of a meeting

and no one reaches down to pick it up, just in case.

Even though when the rain beats down on us we ask Yemayá to make it stop

and when we lose our ring we say the San Gonzalo prayer...

So what's this nonsense about existential agnosticism?

Who on the island is going to believe you?

It is true that a nation invents and reinvents itself

but I remain afloat because all I carry with me are

three obsessions (Amadeus, suffering from nostalgia, finding Valerio),

four and a half ideas (yes, no, yes, no, maybe),

six fruit flavors (star apple, cashew fruit, sugar apple, cocoplum, pineapple, mamey),

seven places (all under a poplar at the Botanic Garden in southeast Havana),

and an anonymous poem with only one word that Columbus wanted

to interpret as "Great Khan" but it was "Cubacabán"—the heart of Cuba...

It is raining and I am bathing in the sea under the star

of a millennium refusing to be born at a dance in the country with a history that binds,

a history that requires accountability, a history hidden underneath.

My story floats and swims, it cannot be heavy or burden me

because as everyone knows it is surrounded by water

everywhere.

It is about moving on without owing anything

- that is what the heroes and martyrs really wanted,

otherwise they wouldn't be real heroes and martyrs.

A story as individual as me, not of the masses,

as much without power as without sharks...

At least that is how I imagine it as I swim freestyle,

in the same love of a weightless nation.
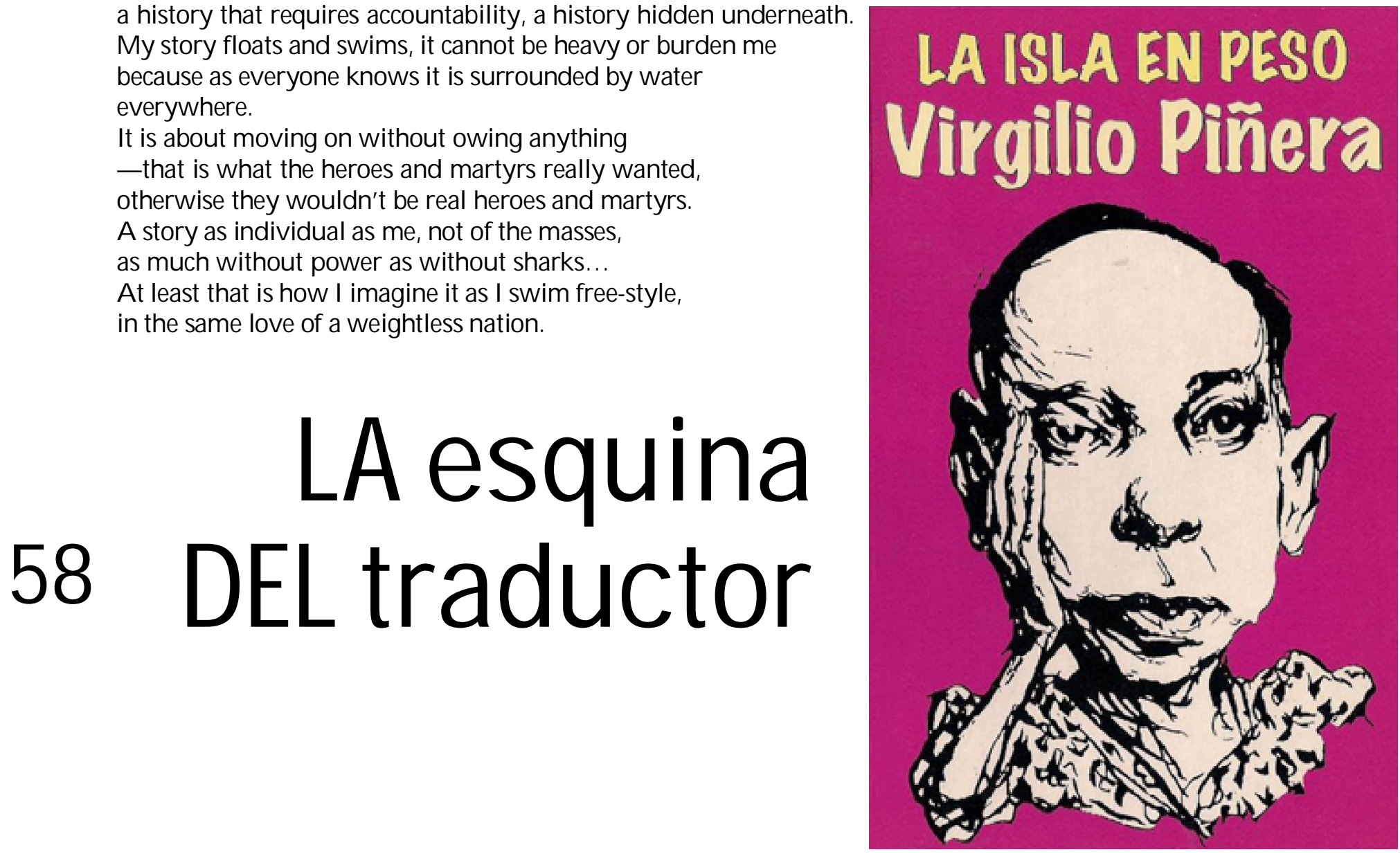